\title{
The aperture and its closure in an Ordovician conulariid
}

Consuelo Sendino, Kamil Zágoršek, and Zdeňka Vyhlasová

Acta Palaeontologica Polonica 56 (3), 2011: 659-663 doi: http://dx.doi.org/10.4202/app.2010.0028

The conulariids, an enigmatic fossil group believed to be of cnidarian (scyphozoan) affinity, have four-sided, acutely pyramidal exoskeletons terminated in apertural closures. To date, three main closure types have been recognised in conulariids (plicated, triangular lappets, and lobate lappets) but the first type is poorly illustrated in the literature. Here we present the first photographic illustration of an unequivocal plicated closure in Metaconularia? anomala, based on study of the rich (1700+ specimens) material from the Upper Ordovician of the Prague Basin. This closure is formed by inwardly folded, triangular lappets centred on each of the four faces, with kite-shaped elements centred on the four corners forming a webbing between the lappets. Plicated closures were evidently rare in conulariids and restricted to a few Ordovician species.

Consuelo Sendino [c.sendino-lara@nhm.ac.uk], Department of Palaeontology, Natural History Museum, Cromwell Road, London SW7 5BD; Kamil Zágoršek [kamil zagorsek@nm.cz], Paleontologické oddělení, Národní muzeum, Václavské nám. 68, CZ - 11579 Praha 1 (CZ); Zdeňka Vyhlasová [vyhlaska@ volny.cz[, Department of Palaeontology, Museum of West Bohemia in Pilsen, Kopeckého sady 2, 30136 Pilsen (CZ).

This is an open-access article distributed under the terms of the Creative Commons Attribution License (for details please see creativecommons.org), which permits unrestricted use, distribution, and reproduction in any medium, provided the original author and source are credited. 
